\title{
VACUUM PRESSURE INFLUENCE ON WATER UPTAKE AND QUALITY OF RICE GRAIN DURING SOAKING
}

\author{
M.E. Yehia ${ }^{1}$
}

\section{ABSTRACT}

The soaking time can be reduced by minimizing the effect of air which is trapped in the caryopsis and between it and the husk. This air resists water movement into the kernel. This paper explores the use of a vacuum and then breaking the vacuum when the paddy rice is soaked to reduce volume of the air, for paddy rice (Giza 181). This would reduce the soaking time in cold water and leads to improvement in the quality of parboiled rice. The simple technique is used to be suitable for poor villages in Africa and Asia where there is no electricity and used rice boiled in their own homes. By using the a pump in four levels of absolute vacuum deareation as 400, 600, 800 and $1000 \mathrm{mbar}$ at $30^{\circ} \mathrm{C}$ the moisture content of paddy rice was determined before soaking and after different times 1, 2, 4, 6 and 12 hours from the beginning of soaking. The results showed that the samples moisture absorption affected by the levels of vacuum, and the sample evacuated at 400 mbar absorbed a few amount of water more than the sample at 1000 mbar. The increasing in moisture gain due to vacuum levels was evaluated. Becker's diffusion equation was used to predict some soaking behavior of paddy; the moisture gain in the grain was noted experimentally and plotted against the square root of the absorption time under different vacuum conditions. Quality tests show that the process of vacuum deareation before soaking improved the parboiled rice quality substantially, breakage varied from 12 to $14 \%$ for raw paddy while for parboiled paddy it varied from 1.6 to $2.1 \%$. Also white bellies decreased from $8.5 \%$ to $5.4 \%$, and hardness was increased from $7.8 \mathrm{~kg}$ to $9.3 \mathrm{~kg}$ when vacuum levels changes from 1000 mbar to 400 mbar.

Keywords: parboiled rice, vacuum pressure, water uptake, soaking

${ }^{1}$ Res., Rice Technology Training Center, field crops research institute, A. R. C. Alex. Egypt 


\section{INTRODUCTION}

$\mathbf{R}$

ice parboiling is an important process in the rice industry. Parboiling of paddy is a hydro-thermal process/treatment that may be defined as the gelatinization of starch within the rice grain. It changes the starch from crystalline form to an amorphous one and as a result of this transformation, the orderly polyhedral structure of the compound of starch granules changes into a coherent mass acquiring a greater strength to resist milling forces and thereby less breakage and lesser loss of nutrition (Sridhar \& Manohar, 2003). It consists of three different operations namely: soaking in water, steaming to complete gelatinization of the starch and drying. The soaking process is essential since water is necessary for an adequate gelatinization (Bandyopadhyay \& Roy, 1978). Theoretically, soaking of paddy can be done at, or below, its gelatinization temperature. The lower the temperature used, the slower is the process of soaking and vice versa. However, the temperature may not be more than $75^{\circ} \mathrm{C}$, or the paddy will get cooked. The higher temperature of steam and the longer the steaming time, changed the harder of rice and darker its color. Keeping steamed paddy in a heap is equivalent to prolonged steaming and induces the same effect. Shade or lower temperature drying gives an excellent milling quality but takes longer time.

The grain ultimately absorbs water up to about $35 \%$ which is considered the required level for an efficient gelatinization. A minimum of 0.40 $0.45 \mathrm{~kg} / \mathrm{kg}$, dry basis, moisture content (depending on rice variety) is usually required to attain complete gelatinization inside the grain and penetration of water into the rice kernel is important as this process results in less breakage during milling, thus increasing yield and milling efficiency (Bhattacharya, 1985).

The application of vacuum or pressure has been found to improve the rate of hydration of grains. Weinecke et al. (1963) reported increased hydration rate of maize less than 1.25 to $6.25 \mathrm{kPa}$ vacuums than at atmospheric pressure. Reduction of this process time and energy requirements needs an understanding of soaking characteristics of paddy. In an effort to reduce these difficulties Iengar et al. (1972, 1974a, 1974b) soaked paddy in cold water for about $48 \mathrm{~h}$, drained off the water and 
followed this by open steaming for $5 \mathrm{~min}$. Although this process reduced the hydration time, the resultant rice was difficult to cook and had a very hard texture. Velupillai and Verma (1982) found that the pressure hydration of rice prior to parboiling significantly reduced the soaking time. Luh and Mickus (1980) reported that the pressure hydration reduced total operating cost due to increased production rate, however, soaking temperatures below that of starch gelatinization are recommended to minimize splitting of the kernels and the subsequent leaching of solids. Kulkarni and Bal (1982) studied the effects of soaking paddy under vacuum. They found an increased moisture absorption and gelatinization of starch for paddy subjected to vacuum than for direct soaking at higher $\left(70\right.$ and $\left.80^{\circ} \mathrm{C}\right)$ temperatures, for a soaking period ranged from $15 \mathrm{~min}$ to $6 \mathrm{~h}$

Soaking is a slow process controlled by the diffusion of water in the grain Engles et al (1986). Thus soaking at room temperature may provoke microbial contamination which affects color, taste and smell of the product. Warm-water soaking is a common method to shorten the soaking time, because increasing temperature increases hydration rate. Some alternative methods were proposed to reduce the soaking time. Bakshi and Singh (1980) found that soaking of dehulled rice can be completed in one-half of the time required for soaking of raw rice. More recently, Kar et al (1999) proposed a parboiled method starting from dehulled rice instead of raw rice. The soaking time can be reduced by minimizing the effect of air which is trapped between caryopsis and husk. This air which is resisted water movement into the kernel. The volume of the air can be reduced by applying a vacuum and then breaking the vacuum when the paddy rice is submerged. The soaking time can be reduced by employing slightly elevated temperatures, since higher rates of water uptake are associated with higher temperatures (Hsu, 1983; Hsu et al 1983; Suzuki et al 1977). The overall rates of water uptake and the equilibrium moisture content increased with pressure and temperature. The effective diffusion coefficient, on the other hand, did not follow the same trend (Ahromrit et al, 2004). The application of high pressures during soaking has been found to enhance water uptake by corn grains (Muthukumarappan \& Gunasekaran, 1992). In addition to 
shortening the over- all process times, the application of high pressures combined with elevated temperatures has other advantages. For example, the generation of favorable starch gelatinization properties is a potential benefit of high pressure processing (Muhr \& Blanshard, 1982) Processing condition such as mode and degree of soaking of paddy influences water uptake capacity of the rice grain. In continuation of a previous work (Igbeka et al. 2008), Dauda \&Igbeka, 2009, studies investigates the effect of steam pressure, specific volume of steam and rice variety on the water absorption behavior on milled parboiled rice.

\section{OBJECTIVIS}

Introduce a simple technique of paddy soaking under vacuum pressure using a hand pump to poor villages in Africa and Asia where there is no electricity and used rice boiled in their own homes. This technique may reduce the soaking time in cold water and leads to improvement in the quality of parboiled rice

\section{MATERIALS AND METHODS}

Raw Materials: The present study was carried out during 2009 rice growing season. A sample of the rice variety Giza181 grown under the normal conditions at the farm of Rice Research \& Training Center, Sakha, Kafr El-Sheikh, was taken at the laboratories of Rice Technology Training Center, Alex., Egypt, cleaned, graded, divided into samples, packed and stored until used at $5^{\circ} \mathrm{C}$ in controlled environment room until experiments.

Cleaning: Paddy rice was first mechanically cleaned to remove foreign materials such as straw, soil particles, mud balls and weed seeds according to the different shapes, sizes and specific weight. Such cleaning may be done by using a precleaning electric apparatus, CaterDay Dockage tester (Model TRG). The apparatus consists of four oscillating and replicable sieves. After precleaning the paddy rice was sorted according to thickness, immature grains of less than $1.6 \mathrm{~mm}$ were separated out, while thicker grains were discharged through the outlet to the receptacle. To ensure high degree of cleanliness, recycling in the apparatus was done. Mechanical cleaning may be completed by hand. 


\section{Physical and mechanical properties of paddy}

Moisture content determination: moisture content of the paddy rice samples were evaluated using Natural Convection Oven Technique model WS- 3 at $130{ }^{\circ} \mathrm{C}$ for 16 hours.

Seed index (1000 - grains weight) in grams: One thousand of paddy grains were weighted by using Rice Grain Counter, model K131 made of aluminum for 500 grains. Ten Random samples, each of 1000 grains were draw from the total number of filled paddy grains.

Grain dimensions: The grain shape tester model MK-100 with measuring range zero to $20 \mathrm{~mm}$ with an accuracy of $0.01 \mathrm{~mm}$ is used. An average of 100 random paddy rice for every samples taken and measured the grain length, thickness and width and then recorded.

Grain shape: Grain size and shape are among the first criteria of rice quality that breeders consider in developing new varieties. The grain shape is the ratio of length/width. It gives indicator about the type of variety and filling grains. Of course it helps to select the sieves and adjust the clearance between the rubber rollers.

Hardness: Hardness of the grain has close relationship with the quality. A hardness tester model KY - 140 was used to measure the breaking force of the grains. The maximum force of $20 \mathrm{Kg}$ can be applied by the plunger of $5 \mathrm{~mm}$ diameter.

\section{Milling process}

Husking: The first step in the actual milling operation of rice is removal of hulls to obtain brown rice. Therefore, a Satake laboratory rubber rolls Sheller model (THU-35A) with a capacity of $40 \mathrm{~kg} / \mathrm{hr}$. was used from the outside we can confirm the husking condition. Brown rice, husks and immature paddy are separated by an aspirator automatically. The Sheller consists of two rubber rolls, each of $100 \mathrm{~mm}$ diameter and $35 \mathrm{~mm}$ wide. The rolls are driven mechanically by motor $400 \mathrm{~W}$, and rotate in opposite inward directions.

Milling: A Satake Testing Mill model (TM-05), with an input capacity of 200 grams of brown rice in one time, was used. This whitening machine consists of abrasive roll $\neq 36$ and rotates at a speed of $450 \mathrm{rpm}$. The bran layer is removed from the brown rice as a result of the friction between rice kernels and both cylinders. 


\section{Measuring of water uptake:}

The techniques of measuring water absorption of grains were interesting of several researchers. In order to evaluate soaked grain moisture content, excess water has to be removed from the grain surfaces. Beeker (1960) developed a method to remove the excess surface water of wheat kernels after soaking by using blotting papers, also Bandyopadhyay and Roy (1976) reported the technique similar to Beekers' technique with paddy grains. For these techniques, it is possible that significant losses of moisture occur during surface drying according to the hand speed and pressure which is different from one to another. A centrifugal technique of Soliman and Yehia (1994) was followed to remove the excess surface water. The soaked samples of amount 25 grams were packed in a muslin bag and it was put inside the bowl of centrifuge with the diameter of 20 $\mathrm{cm}$ and rotates at $1450 \mathrm{rpm}$ for 30 seconds. Three replicates for each sample were done in one run.

Soaking apparatus; Cecil's technique were used for experimental tests. The system consists of a hand pump, a vacuum receiver attached by manometer, polyethylene bags of small sizes connected with plastic pipe and plastic strips and clips for the fastening of the bags. The additional supplies were purchased in order to establish the system for tests.

\section{Water Uptake Theory}

Moisture diffusion in grains takes place because of the moisture gradient between the surface and the centre (Becker, 1960). Absorption of water into the rice kernel can be regarded as a process of diffusion during which a proportion of the absorbed water becomes immobilized during gelatinization as diffusion proceeds (Bandopadhyay \& Ghose, 1965). For the purpose of modeling and to understand a mass transfer process like hydration of paddy, knowledge of the value of diffusivity is required. A number of researchers formulated a mathematical model of nonstationary state diffusion in solids of arbitrary shape from Fick's law of diffusion and utilized this to correlate the weight increase of wheat kernels during immersion in water (Becker, 1959, 1960; Floros \& Chinnan, 1989). They took the first term of the series equation and accounted for the arbitrary shape of the wheat kernel by defining a shape factor. 
PROCESS ENGINEERING

The diffusion model of Becker (1960)

$$
\left(\mathbf{m}-m_{0}\right)=\mathbf{k}_{\mathbf{m}} \sqrt{t}+\mathbf{m}_{\mathbf{i}}
$$

where

$$
\mathbf{k}_{\mathbf{m}}=\left(\mathbf{2} / \pi^{\mathbf{0 . 5}}\right)\left(\mathbf{m}_{\mathrm{s}}-m_{0}\right)(\mathrm{s} / \mathbf{v}) \mathbf{D}_{m}^{0.5}
$$

and where: $m_{0}$ is the initial, uniform moisture content in dry basis. $m$ is the average moisture content for a given absorption time, in dry basis.

$m_{s}$ is the moisture content of the bounding surface, in dry basis.

$\mathrm{s}$ is the exposed surface area of solid (paddy grain) in $\mathrm{cm}^{2}$.

$\mathrm{v}$ is the volume of solid (kernel)in $\mathrm{cm}^{3}$.

$\mathrm{D}_{\mathrm{m}}$ is the diffusion coefficient in $\mathrm{cm}^{2} / \mathrm{sec}$.

$t$ is the absorption time, sec.

$\mathrm{m}_{\mathrm{i}}$ is the constant of absorption equation.

$\mathrm{k}_{\mathrm{m}}$ is the constant.

Biswas and Ghose (1973) modified Equation (2) attributing Arrheniustype relationship for the diffusional process, which is given by

$$
D_{m}=D_{0} \exp (-E /(R T))
$$

where: $D_{0}$ is the diffusion constant in $\mathrm{cm}^{2} / \mathrm{sec}$;

$\mathrm{E}$ is the activation energy in cal $/ \mathrm{mol}$;

$\mathrm{R}$ is the universal gas constant, $1.9889 \mathrm{cal} / \mathrm{mol} . \mathrm{K}^{\mathrm{O}}$;

$\mathrm{T}$ is the absolute temperature in $\mathrm{K}^{\mathrm{O}}$.

Combining Equations (2) and (3),

$$
\begin{aligned}
& \mathbf{k}_{\mathbf{m}}=\left(\mathbf{2} / \pi^{\mathbf{0 . 5}}\right)\left(\mathbf{m}_{\mathbf{s}}-\mathbf{m}_{\mathbf{0}}\right)(\mathbf{s} / \mathbf{v})\left[\mathbf{D}_{\mathbf{0}} \exp (-\mathrm{E} /(\mathbf{R T}))\right]^{0.5} \\
& \text { or } \\
& \mathbf{k}_{\mathrm{m}}=\mathrm{C}[\exp (-\mathrm{E} /(\mathbf{R T}))]^{0.5} \\
& \text { where C }=\left(\mathbf{2} / \boldsymbol{\pi}^{\mathbf{0 . 5}}\right)\left(\mathbf{m}_{\mathbf{s}}-\mathbf{m}_{\mathbf{0}}\right)(\mathbf{s} / \mathbf{v}) \mathbf{D}_{\mathbf{0}}^{\mathbf{0 . 5}} \text {, and is a new }
\end{aligned}
$$
constant,

By taking the logarithm on both sides of Equation (5),

$$
\log k_{m}=\log C-(0.4343 / 2)(-E / R)(1 / T)
$$

$E, \boldsymbol{R}$ and $\boldsymbol{C}$ being constants for a particular variety of paddy, a plot of $\log$ $\mathrm{k}_{\mathrm{m}}$ versus $1 / \mathrm{T}$ would give a straight line. The slope of this line is $(0.4343 / 2)(\mathrm{E} / \boldsymbol{R})$ from which the value of activation energy, $\mathrm{E}$ for the 
process could be evaluated and the value of $\mathrm{C}$ is obtained from the intercept. Knowing the values of $\boldsymbol{C}$ and $\boldsymbol{E}$, the value of $\boldsymbol{K}_{\boldsymbol{m}}$ is determined for soaking.

In Equation (4), $\boldsymbol{m}_{\boldsymbol{s}}$ and $\boldsymbol{m}_{\boldsymbol{o}}$ are constants for a particular type of grain and the volume to surface area ratio may be taken as constant irrespective of moisture content (Becker, 1960). Becker proved the validity of the Equation (1) with soaking data of a particular variety of wheat, by determining diffusion coefficients in wheat kernels and found that absorption of liquid water by the wheat kernel proceeds by a heterogeneous mechanism. Studies conducted by Becker (1959, 1960); Bandopadhyay and Ghose (1965); Biswas and Ghose (1973) and Bandopadhyay and Roy (1980) showed that Equation (1) can be used for the prediction of moisture content as a function of time and temperature of soaking with the following assumptions: (1) during soaking grain is considered to be isothermal (heat transfer equations are neglected); (2) swelling is negligible during soaking; and (3) only radial diffusion is considered.

The spherisity of grains $(f)$ was computed according to Mohsenin (1984) as follows:

$$
f=(\mathrm{LWH})^{1 / 3} / \mathrm{L}
$$

where: $\mathbf{L}$ is the length of the grain in $\mathrm{mm} ; \mathbf{W}$ is the width of the grain in $\mathrm{mm}$; and $\mathbf{H}$ is the thickness, in $\mathrm{mm}$.

The surface area to volume ratio was calculated by dividing the equivalent volume of sphere by surface area of the grain (Chung \& Fan, 1961), given as

$$
\mathrm{s} / \mathrm{v}=4.836 / \mathrm{v}^{1 / 3} \text {. f }
$$

\section{EXPERIMENTAL PROCEDURE}

Experimental design was performed in order to fit the requirements of the objectives concerning the evacuation and their effects on the soaking time and the quality of parboiled paddy rice.

Samples of three kilograms of paddy rice were dearated using the hand pump in four levels of absolute vacuum deareation as 400, 600, 800 and $1000 \mathrm{mbar}$ at $30^{\circ} \mathrm{C}$. the moisture content of paddy rice was determined 
before soaking and after different times 1, 2, 4, 6 and 12 hours from the beginning of soaking.

Soaked paddy rice were boiled at $95^{\circ} \mathrm{C}$ for 15 minutes without pressure and then dried using unheated air. The quality tests were conducted including white bellies\%, broken\%, and hardness. The treatments were conducted in three replicates.

\section{RESULTS AND DISCUSSIONS}

\section{Physical characteristics of Giza 181 paddy rice variety}

The average values of each of physical characteristics parameters were: initial moisture content of the samples $14.911 \%$ (d.b.); the length, width and thickness of paddy 8.76, 2.73 and $1.97 \mathrm{~mm}$, respectively; length to width ratio 3.17; volume of one kernels $19.5 \mathrm{~mm}^{3}$; particle and bulk density 1214.7819 and $554.9359 \mathrm{~kg} / \mathrm{m}^{3}$ respectively; grain index 28.1 grams/1000 kernels; hardness $5.6 \mathrm{~kg}$ and the spherisity 0.41 .

\section{Moisture absorption}

The absorption of moisture content with time at the four different absolute vacuum levels 1000, 800, 600 and 400 mbar were shown in table (1) and figure (1) respectively.

Earlier researchers (Priestley, 1976, Bandopadhyay \& Roy, 1980 and Yehia, 1989) have concluded that hydration of paddy is completed when it attains a moisture content between 40 and $42 \%$ (d.b.) and when no white or opaque spot is observed in the central zone of pericarp or endosperm and translucence of the grain is uniform throughout.

Table (1): Moisture gain versus vacuum levels and absorption time

\begin{tabular}{|c|c|c|c|c|c|c|c|c|}
\hline & \multicolumn{3}{|c|}{ Moisture Content, (\% d.b.) } & \multicolumn{3}{c|}{ Moisture Gain, Decimal (d.b.) } \\
\hline $\begin{array}{c}\text { Time, } \\
\text { hours }\end{array}$ & $\begin{array}{c}400 \\
\text { mbar }\end{array}$ & $\begin{array}{c}600 \\
\text { mbar }\end{array}$ & $\begin{array}{c}800 \\
\text { mbar }\end{array}$ & $\begin{array}{c}11000 \\
\text { mbar }\end{array}$ & $\begin{array}{c}400 \\
\text { mbar }\end{array}$ & $\begin{array}{c}600 \\
\text { mbar }\end{array}$ & $\begin{array}{c}800 \\
\text { mbar }\end{array}$ & $\begin{array}{c}1000 \\
\text { mbar }\end{array}$ \\
\hline 0 & 14.911 & 14.911 & 14.911 & 14.911 & 0 & 0 & 0 & 0 \\
\hline 1 & 29.146 & 28.261 & 27.961 & 26.958 & 0.14235 & 0.1335 & 0.1305 & 0.12047 \\
\hline 2 & 33.198 & 32.243 & 31.711 & 30.387 & 0.18287 & 0.1733 & 0.1680 & 0.15476 \\
\hline 4 & 37.429 & 36.298 & 35.613 & 34.025 & 0.22518 & 0.2138 & 0.2070 & 0.19114 \\
\hline 6 & 39.787 & 38.375 & 37.584 & 35.816 & 0.24876 & 0.2346 & 0.2267 & 0.20905 \\
\hline 12 & 44.562 & 42.751 & 41.632 & 39.657 & 0.29651 & 0.2784 & 0.2672 & 0.24746 \\
\hline
\end{tabular}




\section{Diffusion coefficients}

The moisture gain in the grain was noted experimentally and plotted against the square root of the absorption time under different vacuum conditions based on equation (1). Typical plots of data are shown in figure (2).

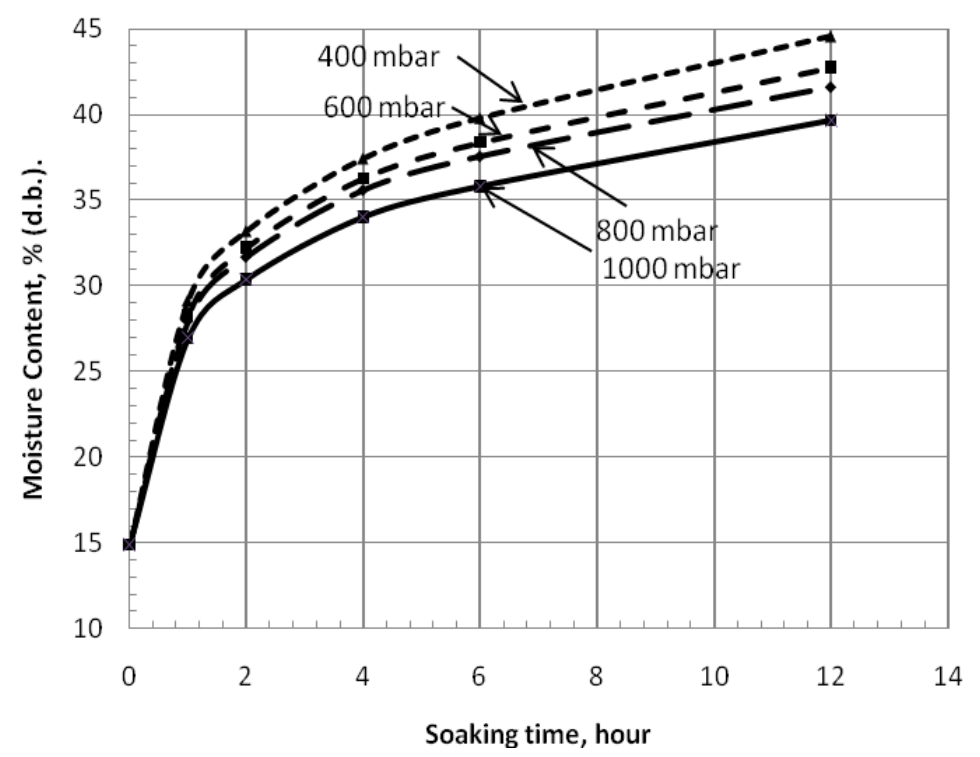

Figure (1): Effect of different vacuum levels on moisture absorption of paddy rice as a function of soaking time per hour.

The linearity of the plot figure (2) proves that the hydration is proportional to square root of the hydration period of paddy grains. The slopes of lines give values for $\mathrm{k}_{\mathrm{m}}$ at different levels of vacuum where at $400 \mathrm{mbar}$ were found to be 0.001389 , at $600 \mathrm{mbar} 0.001306$, at $800 \mathrm{mbar}$ 0.001252 and at 1000 mbar 0.001159 . The intercepts give values for $\mathrm{m}_{\mathrm{i}}$ (initial moisture gain) which has been interpreted by Bandyopadhyay and Roy (1975 \&1976), as very rapid absorption of water into the void space between husk and the pericarp and into the pores of the pericarp by capillary motion. The values of $\mathrm{m}_{\mathrm{i}}$ were calculated and presented as $0.039187,0.037366,0.036225$ and 0.034094 at different absolute vacuum pressure from 400 to 1000 mbar respectively. 


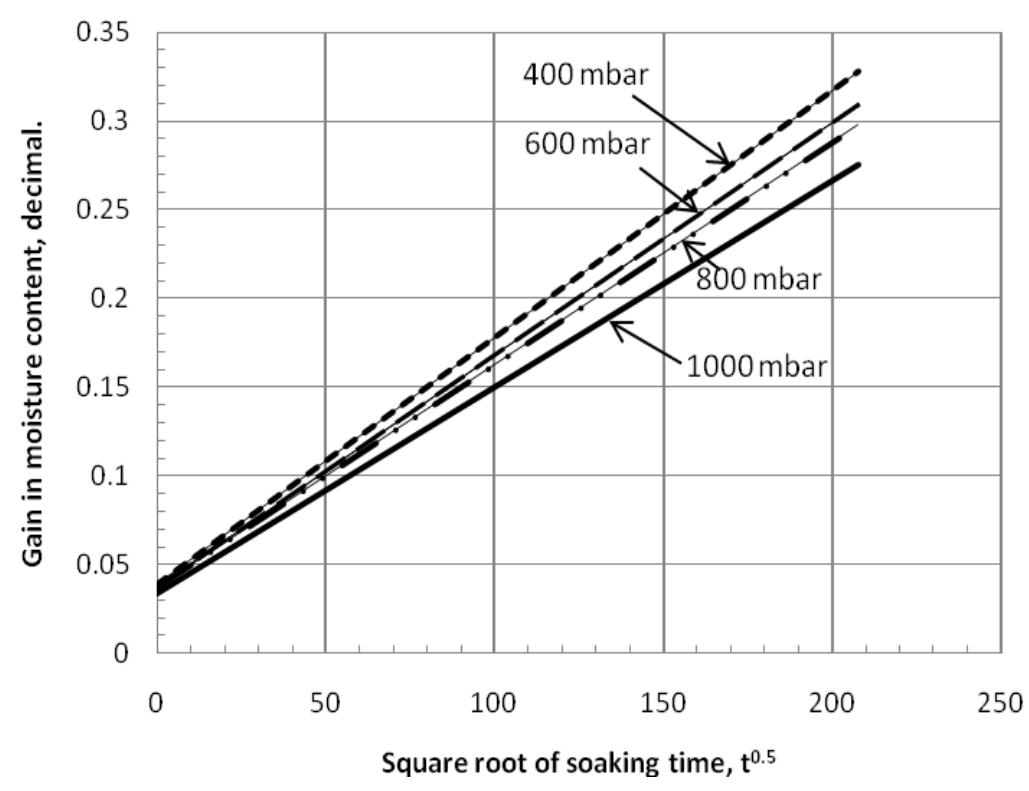

Figure (2): Moisture Gain as a function of the square root of soaking time at different vacuum levels.
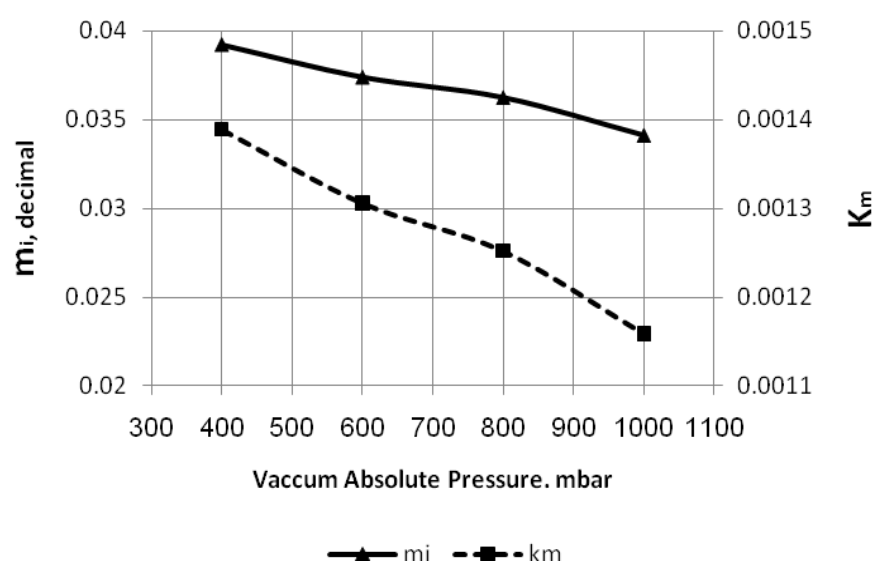

Figure (3): Values of $k_{m}$ and $m_{i}$ as a function of absolute vacuum pressure.

The values of $k_{m}$ and $m_{i}$ as a function of absolute vacuum pressure were represented in figure (3). Prediction equations were established to correlate the values of $\mathrm{k}_{\mathrm{m}}$ and $\mathbf{m}_{\mathbf{i}}$ as a function of absolute vacuum pressure $\left(\mathrm{V}_{\mathrm{L}}\right)$ using linear regression analysis as follows: 


$$
\begin{array}{lc}
\mathrm{K}_{\mathrm{m}}=-4 \mathrm{E}-07 \mathrm{~V}_{\mathrm{L}}+0.0015 & \mathrm{R}^{2}=0.991 \\
\mathrm{~m}_{\mathrm{i}}=-8 \mathrm{E}-06 \mathrm{~V}_{\mathrm{L}}+0.0425 & \mathrm{R}^{2}=0.988
\end{array}
$$

According to Yehia (1989) the surface to volume ratio (s/v) of paddy grain Giza 181 was found to be $4.6151 / \mathrm{mm}$, radius (a) was $1.671 \mathrm{~mm}$ and volume of the grain $19.4741 \mathrm{~m}^{3}$. The plot of $\log \mathrm{Km}$ against the reciprocal of the different absolute temperature can be calculated but in this experiment we used only one level of temperature. The values of activation energies and constant $\mathrm{C}$ [can be calculated from the slopes and intercepts, from equation (6) respectively, of Arrhenius lines for the prediction of moisture content as a function of time and temperature of soaking at a known pressure.

\section{Milling performance}

Within the experimental range of evacuated and moisture absorption studied, the data on extent of quality tests clarify show that the process of vacuum deareation before soaking improved the parboiled rice quality, breakage varied from 12 to $14 \%$ for raw paddy while for parboiled paddy it varied from 1.6 to $2.1 \%$ showing that defective milling quality in raw paddy can be corrected by parboiling. Also white bellies decreased from $8.5 \%$ to $5.4 \%$, and hardness was increased from $7.8 \mathrm{~kg}$ to $9.3 \mathrm{~kg}$ when vacuum levels changes from $1000 \mathrm{mbar}$ to $400 \mathrm{mbar}$.

\begin{tabular}{|c|c|c|c|c|}
\hline & \multicolumn{4}{|c|}{ The quality of parboiled rice evacuated at different } \\
vacuums levels
\end{tabular}

The decrease in head rice yield due to vacuum deareation before soaking may be attributed to kernel defects such as cracks, white bellies percentage and the hardness. This observation was in conformity with the earlier workers (Craufurd, 1962; Hogan, 1967) on breakage of rice during milling. 


\section{CONCLUSION}

The moisture absorption by paddy rice affected by each of vacuum treatments and soaking water temperature, for that normal hot water soaking at $30^{\circ} \mathrm{C}$ is not sufficient for complete parboiling in suitable time, may be more than $60^{\circ} \mathrm{C}$ can be used. The high levels of vacuum which can be achieved by the hand pump 400 mbar (absolute pressure) was very difficult, so we suggest to design a manual vacuum pump working by paddle. It has been successfully reached the end of the soaking stage in a short time where it needs to about 36 hours. The physical and mechanical grain rice has improved significantly and gave good indicators of the percentage of whole grain and all milling quality. The results have show that the application of vacuum pressure can be utilized in the poor villages in Africa and Asia where no electricity available.

\section{REFERENCES}

Ahromrit, A., Ledward, D.A., Niranjan K. (2006).High pressure induced water uptake characteristics of Thai glutinous rice, Journal of Food Engineering 72, 225-233.

Bakshi, A. S., \& Singh, R. P. (1980).Kinetics of water diffusion and starch gelatinization during rice parboiling. Journal of Food Science, 45, 1387-1392.

Bandopadhyay B; Ghose T K (1965).Studies on the hydration of Indian paddy, part I, a rate equation for the soaking operation. Indian Journal of Technology, 3, 360-365.

Bandopadhyay S; Roy N C (1975).Prediction of time of hydration during parboiling of paddy from activation Energy. Journal of Food Technology, India, 12(4), 197-199.

Bandopadhyay S; Roy N C (1976).Kinetics of absorption of liquid water by paddy grains during parboiling. Journal of Food Technology, India, 14, (1), 27-30.

Bandopadhyay S; Roy N C (1980).Desorption characteristics of hot soaked parboiled paddy. Journal of Food Technology, 15, 329-333.

Bandyopadhyay, S., \& Roy, N. C. (1978). A semi-empirical correlation for prediction of hydration characteristics of paddy during parboiling. Journal of Food Technology, 13, 91-98. 
Becker H A (1959). A study of diffusion of solids of arbitrary shape with the application to the drying of wheat kernel. Journal of Applied Polymer Science, 1(2), 212-226.

Becker H A (1960). On the absorption of liquid water by the wheat kernel; Cereal Chemistry, 37, 309-323.

Bhattacharya, K. R. (1985). In B. O. Juliano (Ed.), Parboiling of rice in rice chemistry and technology (pp. 289-348). Minnesota: AACC.

Biswas D K; Ghose T K (1973). \{Hydration of Indian paddy\} Part II. Transactions of Indian Institute of Chemical Engineers, 15(1), 4347.

Chung, D.S.; Fan, L.T. and Shellenberger, J.A., (1961). Volume increase of wheat kernel accompanying absorption of liquid water. J. Biochem. Microbiol. Technol. Engng, 2: 377-381.

Craufurd R Q (1962). Moisture changes in raw and parboiled paddy in West Africa and their influence upon millingquality. Empire Journal of Experimental Agriculture, 30, 321-329

Dauda, S.M.; and Igbeka, J.C. (2009). Water Absorption Behavior of Milled Parboiled Rice in Relationship with Variety and Some Basic Thermodynamic Properties of Steam Au J.T. 13(2):101-106.

Engels C; Hendrickx M; De Samblax I; De Cryze C; Tobback P J (1986). Modeling water diffusion during long grain rice soaking. Journal of Food Engineering, 5, 55-73.

Floros J P; Chinnan M S (1989). Determining the diffusivity of sodium hydroxide through Tomato and Capsicum skins. Journal of Food Engineering, 19, 129-141.

Hogan J T (1967). Processed rice products. Rice Journal, 70(11), 28-31

Hsu, K. H. (1983). Effect of temperature on water diffusion in soybean. Journal of Food Science, 48(4), 1364-1365.

Hsu, K. H., Kim, J., \& Wilson, L. A. (1983). Factors affecting water uptake of soybeans during soaking. Cereal chemistry, 60(3), 208211. 
Iengar N G C; Bhaskar R; Dharmarajan P (1972). Studies on methods of parboiling pressure parboiling. Journal of Agricultural Engineering, 9(4), 40-43.

Iengar N G C; Gangadharan N S; Rajendran G (1974 a). Recent developments in pressure parboiling of paddy. Journal of Agricultural Engineering, 11(1), 31-34.

Iengar N G C; Gangadharan N S; Rajendran G (1974 b). Recent developments in pressure parboiling of paddy direct parboiling. Journal of Agricultural Engineering, 11(5), 28-32.

Igbeka Ray J.C.; Gbabo A.; and Dauda, S.M. (2008). Effect of variety, pressure and specific volume of steam on the head rice yield of milled parboiled rice. J. Food Sci. Technol. 45(3): 282-3.

Kar, N., Jain, R. K., \& Srivastav, P. P. (1999). Parboiling of dehusked rice. Journal of Food Engineering, 39, 17-22.

Kulkarni S D; Bal S (1982). On the influence of evacuation on liquid water absorption. Transactions of the ASAE, 25(5), 1450-1456.

Luh B S; Mickus R R (1980). Parboiled rice. In: Rice: Production and Utilization. (Luh B S, ed). AVI Publishing Co., Inc., West Port, CT, USA.

Mohsenin N N; (1984). Physical Properties of Plant and Animal Materials, Vol. I. Gordon and Breach Science Publishers, New York.

Muhr, A. H., \& Blanshard, J. M. V. (1982). Effect of hydrostatic pressure on starch gelatinization. Carbohydrate Polymers, 2, 61-74.ASAE, 35(6), 1885-1889.

Priestly, R. J., (1976). Studies on parboiled rice. Food chem. 1 (1): 5-8.

Soliman, S.N. and M.E. Yehia. (1994). Steeping characteristic of Egyptian paddy rice. Misr J. Ag. Eng., 11 (1):261-279.

Sridhar B.S; Manohar B (2003). Hydration Kinetics and Energy Analysis of parboiling Indica Paddy. Biosystems Engineering 85(2), 173183. 
Suzuki, K., Aki, M., Kubota, K., \& Hosaka, H. (1977). Studies on the cooking rate equations of rice. Journal of Food Science, 42(6), $1545-1548$.

Velupillai L; Verma L R (1982). Parboiled rice quality as affected by the level and distribution of moisture after the soaking processes. Transactions of the ASAE, 25(5), 1450-1456.

Weinecke L A; Brekko O L; Griffin Jr E L (1963). Vacuum tempering of corn for dry milling. Cereal Chemistry, 40(2), 187-191.

Yehia, M.E. (1989). Steeping characteristics of Egyptian paddy rice. A thesis of MS. Degree. Agricultural engineering department, faculty of agriculture, Alexandria University.

$$
\text { الملخص العربي }
$$

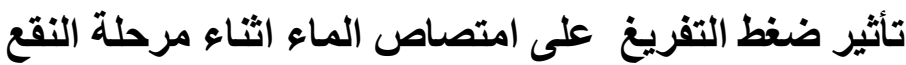

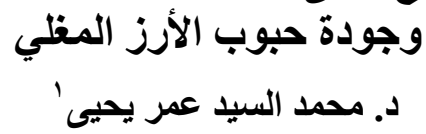

يهدف البحث الي تقديم تقنية بسيطة ومناسبة للقرى الفقيرة في أفريقيا وآسيا و الذين يعتمدون في غذائهم اليومي علي الأرز المغلي وينتجونة في منازلهم باستخدام مضخة تفريغ يدوية (حيث لا لانيان توجد كهرباء) لتقليل زمن النقع للأرز الثعير علي البارد.

تم اجر اء تجارب النقع لعينات في حدود ثلاثة كيلوجر ام لكل عينة للصنف (جيزة الم ال) عند أربعة مستويات من ضغط التفريغ المطلق . .ـ ، . . ، . . ، . . . . (ميلي بار لأزمنة نقع

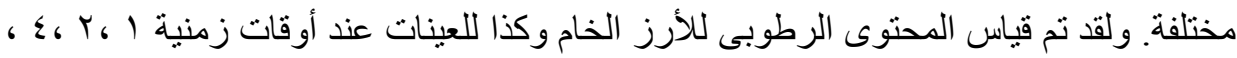

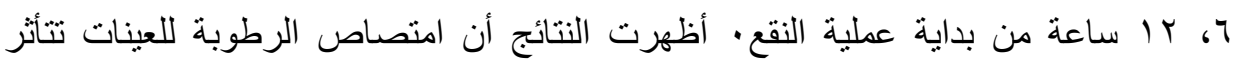
بمستويات ضغط التفريغ حيث وجد ان باستخدام ضغط التفريغ ..؛ ملى بار تم امتصاص كمية من الماء أكبر من استخدام ضغط التفريغ . .. . ملى بار وبالتالى قل الوقت اللازم لاتمام عملية النقع عند استخدام . .ـ ملى بار مقارنة باستخام ل... . . ملى بار وهكذا. تم استخدام معادلة بيكر لإنتشار الكتلة للتنبؤ بسلوك التشرب للأرز أثناء مرحلة النقع تحت ظروف التجربة،

' باحث مركز تدريب تكنولوجيا الأرز بالإسكندريةـ معهل بحوث المحاصيل الحقليةـ مركز البحوث الزراعية 
و رصد العلاقة بين الجذر التربيعى لزمن النقع والمحتوى الرطوبى المتحصل عليه عند هذه

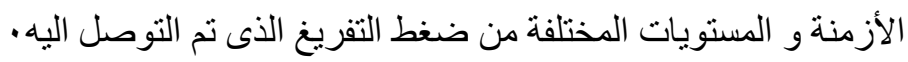

فعملية التفريغ الهو ائي للعينات قبل النقع آدت الي تقليل الوقت اللازم لمرحلة النقع لحبوب الأرز الثعير حيث ان هذا الهواء يقاوم حركة المياه للاخول في الحبة.

ولقد أوضحت النتائج ان استخدام ضغط التفريغ عمل علي تقليل نسبة هذا الفر اغ وبالتالى تقليل حجم الهو اء بين حبة الأرز و القشرة الخارجية (السرس) مما يؤدى الى سرعة التشرب و و تقليل زمن مرحلة النقع باستخدام المياه الباردة. أختبارات الجودة أوضحت أن عمليةاستخدام ضغط التفريغ قبل مرحلة النقع حسن من جودة

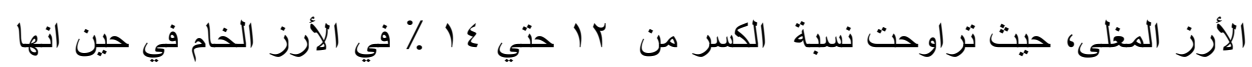

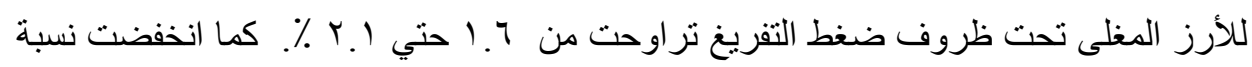

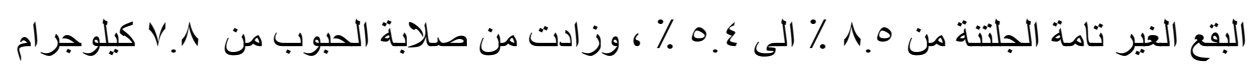

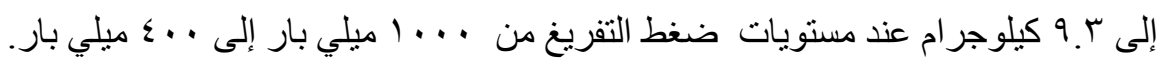

